\title{
Transitional Justice as a Path to Distributive Justice: A Jurisprudential and Legal Case for Land Restitution in Kenya
}

\author{
Claude Kamau*
}

\begin{abstract}
Rawls' theory of distributive justice may serve as a useful model in conceptualizing a model of the ideal political economy - one that seeks to keep inequalities that have come about as a result of natural accident to a minimum. Moreover, his principles of justice can be used correctively, to address institutional inequalities that have the effect of entrenching social dislocation. Kenya has, over the decades up until now, been riven by injustices relating to land. This has led to the development of a small cluster of landed elites while the majority of citizens are effectively denied land access rights. This is regardless of the fact that most of the land so acquired by the former was acquired irregularly and with disregard of bona fide title of the original occupants. The concept and process of transitional justice may be viewed as the vehicle toward attaining corrective justice and accountability for offences committed in times of national crisis as a restorative measure.
\end{abstract}

\section{Introduction}

Kenya, being a constitutional democracy, ${ }^{1}$ is necessarily apt for an analysis of its political economy against the minimum standards imposed by the Constitution. The letter of the Constitution (and of the laws that have been legislated under it) is clear. The question this contribution addresses itself to is whether its

* The author is a student at Strathmore Law School in Nairobi, Kenya.

1 It is noteworthy that Rawls models his theory against the political constitution of a constitutional democracy. Arguably, this makes this theoretical referent more relevant in the case of Kenya. Rawls regards the task of his political philosophy as combining intuitive ideas drawn upon in 'justice as fairness' into a political conception of justice for a Constitutional democracy. 
spirit has been honoured by the institutions and power structures that have been constituted under it. Of particular concern for this article is the land sector, and therefore the extent to which the legal requirements, especially the rights guaranteed under land legislation, have been met.

This contribution will argue that they have not, at least not satisfactorily, and certainly not to the extent that the Constitution envisions. A corollary of this observation is the argument that the power structures that may have lingered from the previous regimes in Kenya have remained oblivious to entrenched injustices respecting land rights. It will be argued that this fact has helped exacerbate the inequities that have persistently and historically characterized the land sector, and, by extension, the cultural and economic lives of most of the citizens.

This contribution will, as a precursor to the discussion above, attempt to conceptualise Kenyan society in light of the ideas of distributive justice, the most prominent and seemingly plausible one being that by Rawls, 'justice as fairness.' This hypothetical will be viewed in the light of Kenya's historical and contemporary situation. The Kenyan land question will be viewed from the perspective of this conception of justice as a negative reference frame; that is, it will be shown that the Kenyan situation falls short of the requirements of this hypothetical 'justice', and that at the moment the two exist in a manner antithetical to each other. This will be done by considering the key expositions of John Rawls and contrasting them to the situation in Kenya. This will reveal that if justice as fairness were the universal bar of evaluating a political economy's faithfulness to guaranteed Constitutional rights, then, in the land sector, Kenya falls awfully short. This discussion will also involve an elaboration of the historical injustices that have actually taken place, their effects on the sections of the population that have been the victims, and the place of this discussion in light of Constitutional rights.

The final part will involve a discussion on how best Kenya can reach this hypothetical (but plausible and arguably incontestable) point of a 'fair' justice. It will be argued that, in view of previous failed attempts at correcting these problems, the best and surest path lies in the process of transitional justice. This is because corrective and restorative justice, from the perspective of this argument, must, in order to address the entrenched injustices to their essence, involve corrective and restorative justice. This process involves accountability on the part of the perpetrators of human rights violations. An important part of this process is to eliminate the false impression of redress of past injustices that the laws may seem to now represent, and instead confront the problem itself-inequitable 
landholding patterns sustained by increased impunity entrenched in the political economy and concealed by the veil of responsive and altruistic legislation. The move is as pragmatic as it is idealistic.

\section{The Rawlsian Hypothetical and Kenya's Land Question Compared}

John Rawls' theory of justice has been among the most prominent contributions by any thinker in the field of political economy. His theory of distributive justice (A Theory of Justice) is based on the idea that society is a system of cooperation for mutual advantage between individuals. As such, it is marked by both conflicts of differing opinions and an identity of shared opinions. ${ }^{2}$ According to Rawls, principles of justice should define the appropriate distribution and burdens of social co-operation. ${ }^{3}$

It should be stressed that Rawls did not expect of his theory of justice to have uniform, unqualified application. Indeed, he notes that there are various conditions that affect a workable conception of justice, and that, ideally, such a conception must allow for a diversity of doctrines defined by members of existing democratic states. ${ }^{4}$ It is for this reason that the argument developed here with relation to 'justice as fairness' is predicated on the particular circumstances of Kenya that render the former applicable to that context.

The academic argument made here is that the distribution of such burdens and advantages in Kenya's land sector falls short of the ideal conceptualized by Rawls. This is a fact that would be established without further historical inquiry with regard to the political antecedents of the landholding patterns in Kenya. However, such further inquiry will reveal, as has been extensively argued and documented, even in Government policy statements, ${ }^{5}$ that the present state of affairs in the land sector has been a result of deliberate political action involving land misappropriation, grabbing as well as illegal and irregular allocations. These actions, spanning the decades of the last century, have led to a system of entrenched inequities in landholding. At this point the argument ceases to be

2 Lacewing M, 'Rawls and Nozick on Justice', Routledge, Taylor and Francis Group, www.alevelphilosophy.co.ke on 31 August 2015.

3 Rawls J, A Theory of Justice, Revised Edition, The Belknap Press of Harvard University Press Cambridge, Massachusetts, 1999, 4.

4 Rawls J, 'Justice as Fairness: Political not metaphysical' 14 Philosophy and Public Affairs Journal, 3 (1985), 223-251.

5 See for instance the National Land Policy, Sessional Paper No. 3 of 2009. 
academic; the assessment is based on facts, and Kenya's history is rife with these facts.

Having established that the present system is not desirable - at least from the perspective of Rawls' 'Justice as Fairness', and that the conditions that have precipitated the present system are decidedly unjust, the argument explored is that of corrective justice geared to a certain kind of distributive justice. This should be a legal process and not a political endeavour. This contribution identifies transitional justice as the most viable route toward this end, for reasons that will be elaborated.

Rawls' project is one of using social contract theory to generate principles of justice for assigning basic rights and duties and determining the division of social benefits in a society. He uses a hypothetical starting point analogous to that of traditional social contract theory. This is a hypothetical because it is not presented as a historical fact, but as an abstract reference frame for building what would come to be viewed as the principles of justice in society. ${ }^{6}$

The distinctive characteristic of this original position is the 'veil of ignorance', which is a figurative representation of the fact that individuals in this position are aware neither of their status in society nor their personal or psychological propensities. The reason why this 'veil' is important in leading up to a certain conception of justice is that the principles generated are:

"the principles that free and rational persons concerned to further their own interests would accept in an initial position of equality as defining the fundamental terms of their association. ${ }^{7}$ These principles are to regulate all further agreements; they specify all kinds of social cooperation that can be entered into and the forms of government that can be established." This way of regarding principles of justice Rawls calls 'Justice as Fairness."

Since all are similarly situated the decisions regulating subsequent interactions are based on common agreement, and no one is able to skew such principles in favour of his particular conditions. The principles so settled upon are to regulate the criticism of all subsequent institutions.

The two principles that would be reached in an original position of fairness and equality are (i) each person to have an equal right to the most extensive basic liberty for others and (ii) social and economic inequalities are to be arranged so

Rawls J, 'Justice as Fairness: Political not Metaphysical', 223-251.

Rawls J, A Theory of justice, 10.

8 Rawls J, A Theory of justice, 33. 
that they are both (a) reasonably expected to be to everyone's advantage; and (b) attached to positions and offices open to all. ${ }^{9}$

The project of justice as fairness is that of using social contract theory to generate principles of justice for assigning basic rights and duties and determining the division of social benefits in a society. Upon a consideration of the general principles predicating the Kenyan legal framework that are of special relevance to equality and justice, the position that best commends itself to us is that it seeks to effectuate, inadvertently or otherwise, some of the main tenets of justice as fairness. Only in this case there is no veil of ignorance but a normative framework that is justice-oriented, a kind of justice as fairness, nonetheless. As will be seen, the same cannot be said of the political realities themselves; these are what is in need of reform if the justice sought is in fact going to be fair. This will become more apparent after the discussion on historical injustices with regard to land, the effects of which persist.

Rawls attaches (an) unimpeachable value to justice as fairness as a guiding principle as well as an end.

Justice is the first virtue of social institutions. Laws and institutions no matter how efficient and well-arranged must be reformed and abolished if they are unjust. Each person possesses an inviolability founded on justice that even the welfare of society as a whole cannot override. ${ }^{10}$

The importance of Rawls' theory to the issue at hand lies not so much in its extensive detail as in its recognition of the inviolability of the individual, which cannot be overridden by such other meta-narratives as efficiency or overall social welfare. Indeed, it has been observed that the Kenyan referent does differ with some areas that are actually important in $A$ Theory of Justice, such as the idea of the veil of ignorance.

The assertion that the individual is inviolable and his interests paramount has strong implications for the concept of distributive justice. This is so because, arguably, one important objection that could be raised against distributive justice or redistribution in particular, is that such a drastic change would spell catastrophe for systemic efficiency sustained over time. It is noteworthy that this objection is not raised against distributive justice as a principle (that there should be a good measure of equality for burdens and benefits distributed by institutions among the members of society), but on its consequences in the market itself. In

$\begin{array}{ll}9 & \text { Rawls J, A Theory of justice, } 289 . \\ 10 & \text { Rawls J, A Theory of justice, } 26\end{array}$ 
fact, this line of thought has informed decisions regarding land allocation and re-allocation as a matter of policy in post-independence Kenya. The lesson to be learnt is that this policy created, in the long run, deeper inequalities whose cost to the Kenyan society far outweighs the potential benefits envisioned by policymakers aiming to sustain the status quo at that point in time. The regnant approach in Kenya's political sphere has historically been, essentially, the prioritisation of economic and other interests when it comes to land allocation, ${ }^{11}$ at the expense of satisfying legitimate entitlements to land. Such an approach is clearly antithetical to the idea of distributive justice in 'Justice as Fairness'. The argument this paper makes is that as a departure to this regnant approach, justice as fairness would demand that every individual be granted (not just guaranteed) their basic liberties under the political Constitution, and this should not be subordinated to economic or other interests. In any event, a departure from this ideal would only be allowable, according to the second principle of justice in justice as fairness, if the (permitted) inequalities are to the greatest benefit of the least-advantaged.

Having established that in justice as fairness the basic liberties of citizens are taken as settled, and that justice as a virtue is uncompromising, we must establish whether these academic (or even transcendental) propositions are actually regarded as sound in the Kenyan legal framework. If our sources in this respect lead us to answer in the affirmative, then, based on available evidence we must not hesitate to conclude that Kenya's landholding patterns are unjust and that, therefore, are incongruent with the (rational) decisions already articulated by the Kenyan populace regarding the principles to which they intend to subject their affairs.

A problem of a rational decision has a definite answer only if we know the beliefs and interests of the parties, their relationships in respect with one another and their alternatives when they have to choose. The simple questions that predicate this discussion would therefore be approximated as the following: Do the provisions of law correctly represent the positions that would be taken by the members of Kenyan society as rational beings? If this question is answered in the affirmative, can the same be said of the landholding patterns, or are they decidedly unequal or unjust, particularly in light of historical circumstances? Does the Rawlsian view of justice, therefore, as a corrective measure, represent a rea-

11 See for instance, Karuti K, 'The legacy of the white highlands: Land rights, ethnicity and the post2007 election violence in Kenya' Journal of Contemporary African Studies; on the various post-independent settlement schemes, and of the attempts by the Independence Government to assuage certain militants who felt the that the land issues were being ignored or shelved. 
sonably sensible ideal? By virtue of the social dislocation caused by land-related conflicts, as well as the inequalities created by misappropriation and irregular allocation as a backdrop against which the new Constitutional dispensation is viewed, is Kenya consequently a society in transition? Finally, is transitional justice, with all factors considered, a viable avenue toward realising the Rawlsian ideal? The following sections try to delineate these considerations along the lines of argument outlined before.

\section{Justice as an Uncompromising Principle in Kenya's Legal Framework}

The spirit that fuelled the clamour for a new Constitution for Kenya and the repealing of all laws repugnant to justice (such as Section 2(a) of the Independence Constitution) in the last two decades is captured well in the body of legal opinion surrounding the Constitution development process. Jackton Ojwang $^{12}$ contrasted the dynamics of Constitution making at independence with those that characterized the Constitution-reform debate in the last decade. This juxtaposition yields the conceptual issues that ought to have been addressed at independence but were not, and the need to address them in contemporary times through a new Constitutional law. Indeed, the Constitution adopted was largely modelled along the dynamics of the Westminster system.

Professor Ojwang's argument can be condensed into three main points. That the Independence Constitution was formulated under the following peculiar factors:

(i) The levels of literacy and education were relatively low. This meant that the possibility of a united people, politically aware and knowledgeable of its rights, which it pursued through a political apparatus, was not really realized. In such a situation, the dominant values of a society or political constituency would not be subject to agreement by consensus.

(ii) The profile of the process was that it was effectively in the hands of a small political elite who were in a position of goodwill and trust which subsisted even after independence. These were susceptible to 12 Ojwang JB, 'Constitutional reform in Kenya: Basic conceptual issues and concepts', in Report of the
Constitution of Kenya Review Commission, 5 (2003)14. 
co-option by the departing European powers as well as tightly circumscribed interests which did not necessarily represent the best for the nation as a whole. This was a political reality that led to an 'ascendant Executive', evidenced by the subsequent amendments to the Constitutions that were primarily political and strategic.

(iii) The net effect of this profile was that the Constitutional order put in place was not truly informed by the social and economic needs of the people.

If these factors can be considered as exempting the Independence Government from blame, moral or otherwise, for failing to be responsive to the imperatives of the social consciousness at the time, the same cannot obtain today. Dialogue leading up to the adoption of the New Constitution has been characterized by an emphasis on public participation and responsive laws. Section 4 of the Constitution of Kenya Review Act ${ }^{13}$ required the development of a new Constitutional document to be conducted in the context of popular participation.

Jackton Ojwang, in outlining the broad reform issues to be addressed by the Constitution, noted that the 'primary interest of the Kenyan people in securing a reformed Constitution will rest upon certain broad social welfare issues. ${ }^{14}$ In any country, he states, citizens expect governance systems to secure values such as equity, justice, peace and tranquillity. The realization of these attributes is a function of power allocation and management. ${ }^{15}$

Even more significant for the purposes of settling basic rights and articulating justice as an uncompromising principle is the Constitution of Kenya. The Preamble to the document articulating its spirit reads, in part: 'recognizing the aspirations of all Kenyans for a government based on the essential value of human rights, equality, freedom, democracy, social justice and the rule of law.'

Article 10(2)(b) includes among the various national values and principles of governance human dignity, equity, social justice, inclusiveness, equality, human rights, non-discrimination and protection of the marginalized.

Article 27(1) provides that everyone is equal before the law; Article 28 further provides that everyone has inherent dignity and the right to have that dignity respected.

Cap. 3A, Constitution of Kenya Review Act.

Ojwang JB, 'Constitutional reform in Kenya: Basic conceptual issues and concepts', 13.

5 Ojwang JB, 'Constitutional reform in Kenya: Basic conceptual issues and concepts', 15. 
Equitable access to land is of particular importance to this discussion. Article 60(1)(a) instructs that equitable access to land is to be a principle of land policy in Kenya. Accordingly, Sections 72 to 75 of the National Land Policy ${ }^{16}$ acknowledge that by virtue of land being a finite resource, there is need to restrict the rights of ownership to facilitate sustainable resource utilization. The Government is entrusted with the duty to facilitate sustainable resource utilization. Section 4 of the Land $\mathrm{Act}^{17}$ further provides that this and other guiding principles relating to land bind all State organs, State officers and public officers as well as any other person who makes or implements such policy.

The foregoing observations doubtless answer our earlier question with regard to the place of basic individual liberties and uncompromising justice in the Kenyan legal framework. The question (posed earlier) must be answered in the affirmative. The crux of the matter, however, lies not in the law; it lies with the fact. The following sections will seek to establish that neither in contemporary nor past Kenyan society, starting from the colonial era, has this ideal been fully realized, let alone the Rawlsian ideal, which is considerably higher and arguably more sophisticated.

Of key importance to the import of the observations above is to understand, historically, the regnant policies in respect to land as well as the relationship between access to land and other fundamental values or rights. This will enable us to bring Rawls' expositions regarding basic rights and entitlements into perspective, in the particular context of Kenya. The highlights of government policy to be discussed below will reveal that fairness has hardly been a priority in land allocation by (primarily the first two) previous governments.

This contribution will propose that equality and social justice in Kenyan society must cease to be a formal equality and instead become a moral and political principle. Once it is established that the landholding system in Kenya is predominantly inequitable and that fair access to land remains a high-sounding illusion (but an illusion, nonetheless), a pragmatic approach must be taken toward the actualization of Constitutional imperatives for actual reform. Once our long-held belief in the determinacy of our legal rules is confronted with the stark realities that prove such determinacy to be a myth, we must begin revising our convictions about the surest mechanisms for eradicating the issues that still subsist and whose resolution has been long overdue.

\footnotetext{
16 Republic of Kenya, Sessional Paper No. 3 of 2009.

17 Land Act No. 6 of 2012.
} 
The following statistics make the issue clear:

(i) Research suggests that smallholder farms in Kenya have been shrinking over time. Roughly forty percent of Kenya's population resides on five percent of its arable land, creating an apparent 'land amidst scarcity abundance. ${ }^{18}$ It has been suggested that this may be because arable land has remained underutilized as it is yet to receive sufficient public investment. The other argument, which is important for the purposes of this paper, is that as in other countries with a colonial settler history, there has been the post-independence continuation of colonial tenure systems separating 'customary lands' from 'state lands. ${ }^{19}$

(ii) Research also indicates that three percent of the population owns 20 percent of the arable land. ${ }^{20}$

(iii) Much of Kenya's unutilized arable land is under state authority, which is not readily accessible for settlement by smallholder populations under prevailing land allocation institutions. ${ }^{21}$

(iv) Lack of access to land is a major determinant of poverty in Kenya. Above eighty percent of the population depends on agriculture and rising inequality in landholding exacerbates this. ${ }^{22}$

(v) Approximately two million people live in Nairobi's informal settlements and slums alone. They make up over half the capital's population yet are crammed into only five per cent of the city's residential area and just one per cent of landin the city. ${ }^{23}$

The landholding patterns in Kenya (which are sustained by the existing power structures) are decidedly inequitable, and therefore unjust. A further argument is made that the same are in violation of Constitutional imperatives and

18 Jayne TS and Muyanga M, 'Land constraints in Kenya's densely populated rural areas: Implications for food policy and institutional reform', Contributed paper prepared for presentation at the $86^{\text {th }}$ Annual Conference of the Agricultural Economics Society, University of Warwick, United Kingdom, 2012, 16-18.

19 The World Bank, Rising global interest in farmland report', Washington D.C, 2011

20 Jayne TS and Muyanga M, 'Land Constraints in Kenya's Densely Populated Rural Areas: Implications for Food Policy and Institutional Reform.'

21 Jayne TS and Muyanga M, 'Land constraints in Kenya's densely populated rural areas: Implications for food policy and institutional reform.'

22 Encyclopedia of the Nations, Kenya- Agriculture, www.nationsencyclopedia.com/Africa/KenyaAGRICULTURE.html on 3 December 2013.

23 Pamoja Trust, An Inventory of the slums in Nairobi (unpublished report), 2009, 10. Citing "Inventory of Nairobi Slums", Matrix Consultants, 1998. 
illegal; this effectively constitutes a denial of the Constitutional right to fair access to land. When understood within the context of Ojwang's expositions about Constitutional principles in contemporary times as ideally articulating social welfare imperatives, it becomes clear that the realities of landholding in Kenya stand in opposition to these imperatives. The upshot of this is that the situation therefore stands in need of reform.

Now it is risky to view such illegality as an absolute, stand-alone declaration of fact. It is important here to make two points. First, the concept that is envisioned by this contribution, and by the Constitution, is fair and equitable access rights and not equal ownership of land as a resource. Second, inequitable distribution becomes unconstitutional (and illegal) in the tightly-circumscribed sense of Article 40 of the Constitution on the protection of the right to property. Sub-section (6) provides that such rights do not accrue to any property that has been acquired illegally. Irregularly acquired land therefore, ipso facto, constitutes an illegality, regardless of the distributive consequences or the implications for the imperative of fair access. Whether redistribution of irregularly acquired property is inherently incontestable as a principle is a question that needs much consideration. For the keen observer, this fact already raises a critical issue what are the implications of the foregoing on the rights of the bona-fide third party title-holders through succession, purchase or otherwise?

At this point we are returned to Rawls' hypothetical. Unequal starting positions in the basic structure of society serve to maintain (and are usually the product of entrenched inequalities. Not only are these inequalities pervasive, but they affect men's initial chances in life, yet they cannot possibly be justified by an appeal to the notions of merit or desert. ${ }^{24}$ Yet according to Justice as Fairness, having prior regard to particular circumstances which produce diverse doctrines of justice ${ }^{25}$, justice as fairness only tries to draw upon basic intuitive ideas that are embedded in the political institutions of a Constitutional democratic regime. ${ }^{26}$ Therefore, these principles should suffice to settle such concerns at a general level.

\footnotetext{
24 Rawls J, A Theory of Justice, 30.

25 Rawls J, 'Justice as fairness: Political not metaphysical', 225.

26 Rawls J, 'Justice as fairness: Political not metaphysical', 223-251.
} 


\section{Historical Injustices Exacerbating Inequities in Landholding}

Several events in Kenya's history have radically transformed the land allocation structure. The original point, which should be kept in mind, is customary land tenure, which seems to represent the highest ideals of inclusiveness and fair (but not necessarily equal) rights of access to land. They have, in one way or the other, constituted the abusive practices mentioned before.

The (ostensibly) legal acts of the colonial government can be said to be predicated on supplanting communal tenure with the introduction of private property in order to entrench the colonial capitalist system that would primarily benefit the settlers, who would own the factors of production, including land. This is essentially land appropriation; it was irregular because it paid no regard to the equitable interest of native occupants of the land, even less their indefeasible title by reason of long and continued possession. ${ }^{27}$

Independence for Kenya brought in its wake, as a corollary to selfgovernment, the promise that Africans would have their property rights restored. Indeed, land rights and poor conditions in the native reserves had been the main grievances that led to the Mau Mau Rebellion. ${ }^{28}$ Moreover, the fact that there had been threats of regrouping by these fighters during the first years of independence, ${ }^{29}$ when it seemed that the Nationalist Government was not intent on redressing these wrongs, demonstrates the centrality of the land question even in post-independence Kenya. Particularly, this demonstrates that the clamour for corrective justice in land has been perpetual and protracted.

The gravity of the land question (essentially, appropriation of large tracts by the Colonial Government) was not helped by the measures adopted by the Independence Government. Settlers wanted to give (sell) their land but on their own terms, to secure their own interests. The administration at independence

For the juridical measures adopted by the colonial government to lay sovereign claim over land, see Foreign Jurisdictions Act of 1890, The Crown Lands Ordinance of 1915, the Kenya Annexation Order in Council as well as the case of Isaka Wainaina v Murito [1922-1923] 2 KLR 102 on the effect of these legislations.

28 This was an uprising by African- mainly Kikuyu- peasantry in the 1950s against the colonial government, the initial grievance being land restitution and later, self-rule.

29 See Anhinga K, 'The Legacy of the white highlands: Land rights, ethnicity and the post-2007 election violence in Kenya, Journal of Contemporary African Studies, on the various post-independent settlement schemes, and of the attempts by the Independence Government to assuage certain militants who felt that the land issues were being ignored or shelved. 
agreed to re-Africanise the highlands but catered for economic stability rather than addressing landlessness. ${ }^{30}$

The government was therefore effectively engaged in a delicate balance between efficiency and equity, a balance which, incidentally, seemed to increasingly tilt toward the former. Rawls would criticize the Independence Government's approach to 'Re-Africanisation' for prioritizing economic stability and neglecting the inherent inviolability of each participant in the social contract notwithstanding the social cost. If the reader may recall, it is a cardinal tenet of justice as fairness that individual liberties should not be subordinated to the sum of calculable interests derived from other considerations. Indeed, each person possesses an inviolability founded on justice that the welfare of society alone cannot override. $^{31}$

As elaborated, the Independence Government, to the extent that it proceeded to allocate land oblivious of the previous property regimes and rights, in favour of political and economic considerations at the expense of equitable land distribution- which had been the primary grievance in the colonial era- did so irregularly. The core tenets of justice as fairness at this time appear to have receded into the background.

If the myopic subordination of the rights of indigenous land-holders to political and economic considerations was the earlier stage in the systemic neglect of their plight, then endemic corruption and overt arrogation of land by those in higher echelons of power was the next.

According to the Ndung'u Report ${ }^{32}$ on illegal and irregular allocation of land, most illegal allocations of public land took place before or soon after the 1992, 1997 and 2002 elections.

Land grabbing has been defined as the taking possession of and/or controlling a scale of land for commercial/industrial or agricultural production which is disproportionate in size (in comparison) to the average landholding in the region. ${ }^{33} \mathrm{~A}$ critical evaluation of this phenomenon reveals two aspects that characterise it. First, abusive practices in the process of acquiring the land, and

30 Kitching G, Class and economic change in Kenya: The making of an African petite bourgeoisie, Yale University Press (1980).

31 Rawls J, A Theory of justice, 3.

32 Ndung'u Report: Land and graft in Kenya.

33 FIAN International, Land grabbing in Kenya and Mozambique: A report on two research missions and a human rights analysis of land grabbing (2010). 
second, the distributional aspects of the phenomenon and its impact on the political economy and the local and national populations' right to resources for both today and the future.

The abusive nature of land-grabbing practices is further illustrated by the political goings-on in the second regime of government in Kenya. This is what is captured by the observation in the report cited above. Land grabbing under this regime reached an unprecedented scale with the advent of political liberalisation in Africa. It has been argued ${ }^{34}$ that 'powerful actors will attempt to maintain patrimonial control by developing creative counter-strategies to change. When faced with declining patronage resources, they will find alternative sources, often amplifying corruption and violence in the process.'

Political liberalization meant that in Kenya, the 90s represented a context of increased political freedom and competition as major aid donors in 1991 coordinated their actions to cut off non-humanitarian balance of payments pending political reforms. ${ }^{35}$ Reduction in aid resulted in concurrent reduction in traditional resources of patronage for the government and in such a context, public land, being highly accessible and less encumbered by international conditions, became an attractive patronage asset. ${ }^{36}$

The second level of the two-pronged analysis of land grabbing and irregular allocation is the distributional aspect. This refers to the impact of these practices on the modern national economy, and equity and access to land as an integral part of human rights and distributive justice. It is at this point, as mentioned in the beginning, that an abstract comparison is drawn between Rawlsian justice as an ideal and the contemporary situation in Kenya.

Forced evictions are an inevitable consequence (in fact, a distributional aspect) of land grabbing if such land is already occupied. Forced evictions themselves are sinister and notorious, and not as nuanced as the underhand dealings that lead up to the grabbing of land. It is regrettable that those on the receiving end of both of these machinations are the (urban) poor; with limited resources at

34 Klopp JM, Pilfering the public: The problem of land grabbing in contemporary Kenya, Indiana University Press.

35 Frank H and Ford M, 'Kenya: Slouching toward Democracy'39 Africa Today, 3 (1992), 97-111.

36 For a detailed account of prominent cases of land grabs by this government see Kanyinga $\mathrm{K}$ 'The legacy of the white highlands: Land rights, ethnicity and the post-2007 election violence in Kenya', Journal of Contemporary African Studies. Particularly, two cases are of note: Westlands Market where an open air market was annexed to foreign private developers and the case of Karura Forest where the government was actively involved in spreading propaganda and false information to conceal the irregular allocation of land. The former case involved disentitling a large community of landholders that had benefited from a government program. 
their disposal to seek redress the fact that they may have equitable property rights or title by reason of long possession notwithstanding.

It has been argued in previous studies that:

'forced evictions are widespread in Kenyan cities and are, on the surface, caused by conflicts in land- rights, non-payment of excessive land and house rents, and urban redevelopment. But, more fundamentally, evictions are due to factors embedded in the country's political economy, in particular, the grossly inequitable land ownership structure which makes it difficult for the poor to access land and decent shelter. ${ }^{37}$

The socioeconomic, cultural and political consequences of evictions include individual and social impoverishment, loss of livelihood and traditional lands as well as physical injury resulting from arbitrary violence.

According to a certain report, ${ }^{38}$ forced evictions violate, directly or indirectly, the full spectrum of civil, cultural, economic, political and social rights enshrined in international instruments. These violations can directly be attributed to the way evictions are carried out, the way they are planned, the way they are decided, the use of harassment, threats or force, and the results of the evictions. ${ }^{39}$

It is important to devote time and effort (especially correctively) to understand the misconceived notions that attempt to rationalise and demonstrate the necessity, as well as constituting the justification, of forced evictions.

It is widely held, for instance, that slums are a drain on the economy and criminally-infested areas deserving of destruction, rather than an integral part of the urban environment. ${ }^{40}$ This notion is, at its root, misleading. Slums and other informal settlements form the base of the informal sector that is a major part of the country's economy. ${ }^{41}$ Specifically, sector contributes labour, employment, income, and markets as well as cheap goods and services that are indispensable to urban economic production and household survival in the country. Socially, due to their vastness and population, they make an important contribution to the nation's social reproduction. Politically, the burgeoning populations in these informal agglomerations form a politically large constituency especially when mobilised, such as at the independence struggle. ${ }^{42}$ Similarly, evictions on the surface

\footnotetext{
37 Otiso KM, 'Forced evictions in Kenyan Cities' 23 Singapore Journal of Tropical Geography, 3 (2002).

38 United Nations (UN) Common Country Assessment for Kenya, 1998.

39 United Nations (UN) Common Country Assessment for Kenya, 1998.

40 Otiso KM, 'Forced evictions in Kenyan cities.'

${ }^{41}$ Otiso KM, 'Forced evictions in Kenyan cities.'

42 Otiso KM, 'Forced evictions in Kenyan cities.'
} 
appear to be caused by the enforcement of municipal planning, building by-laws, government orders, conflict over land rights, political struggles, non-payment of (unjust) land and house rents, state security and urban (re)development. ${ }^{43}$ Fundamentally, however, they are caused by factors embedded in the political economy. Most notable has been the country's land-ownership structure that has precluded many poor people's access to land and decent shelter.

Underlying notions that characterise government policy should be appraised in an equally critical manner to unearth biases and truths. Essentially, any corrective measures regarding land should be aimed, at a broad level, at addressing the attendant problems associated with these historical injustices. 'Justice as Fairness' is instructive in that the principles entered into (for instance, in this case, legal measures for accountability and redress) are the basis for appraising institutions and public offices tasked with reform.

\section{Potential Trade-offs in Attaining the Rawlsian Ideal}

It has been argued repeatedly that one of the core tenets of Justice as Fairness' is that the individual possesses an inviolability founded on justice that even the welfare of a society alone cannot override. ${ }^{44}$ Perhaps it this principle that constitutes the rationale behind Sections 72 to 75 of the National Land Policy (discussed earlier) as well as Article 60 of the Constitution on equal access to land.

It is submitted here that a plausible argument for the protection of slum dwellers from arbitrary eviction through legitimate property rights may be made in light of Article 63(1) of the Constitution that recognises 'similar community of interest' of a certain constituency as a basis to assert rights to community land. It would be of great use to policy-makers to consider the arguments against 'formalising the informal' property. Empirical evidence has demonstrated that there is no necessary causal link between individual land rights and economic growth. ${ }^{45}$ This point has special relevance when it comes to the potential tradeoffs that the Rawlsian ideal presumably implies. If it is proved that there is little

\footnotetext{
43 Apiyo LO, 'Land grabbing and evictions in Kenya' (1998). See here: http://www.africabib.org/rec. php?RID=Q00034933 on 13 December 2015.

44 Rawls J, $A$ Theory of justice, 3.

45 See Ogendo HWO, Formalising the Informal, on the fallacies that characterize the conversion of customary land tenure to private land tenure through individual titling.
} 
to be lost by formalising and titling, which effectively means that land is owned by the title-holder to the exclusion of all others including holders of bona fide interests in land, pragmatic steps can be taken to ensure all basic entitlements are met. The (delicate) 'balancing act' between equity and efficiency is in this case not a factor.

The principles of landholding, use and administration in Article 60 include 'equitable access to land, and 'security of land rights.' Recognition of informal settlements as community land for dwellers and then actively integrating these areas through urban planning would help serve both ends. This view is further informed by the realisation that slums are an important factor in the social, political and economic spheres of the country and thus need to be integrated not arbitrarily wiped out. Moreover, after considering the history of forced evictions it becomes clear that slums cannot really be removed by this means, no matter how frequent and widespread the evictions are. These failings should be enough to guide policymakers towards better, sustainable alternatives. Rawlsian justice articulates tenets that are useful for such a situation going forward. First, the inviolability of the individual and their basic entitlements must be stressed. Secondly, principles of justice entered into by the individuals in society by their free and rational choice are to regulate all further criticism of society's institutions. Thirdly, these principles must be the basis of Constitution and the basic structure of society- essentially institutions charged with distributing benefits (and enforcing burdens) in the society. Uncompromising principles that have been settled by the various land legislations and the Constitution must be considered keenly by these institutions and implemented.

\section{The Way Forward}

These passages have essentially made the point that some events in Kenya's history have served to radically transform the property rights allocation and system of landholding. The original point was that of communitarianism and fair access, the reality today is that ownership of land has been skewed to favour a few elite groups (as compared to the very many smallholders and the landless).

These events have had a profound effect on Kenya's political and social Constitution in a single but important way; they have served to entrench socioeconomic inequities in the political economy of the country. The power structures in place have not managed to disentangle themselves from status quo considera- 
tions and have in this way not responded effectively to these injustices. Landholding and land access structure is important for organisation and economics in a society. Also, such structures reflect how power is held. ${ }^{46}$ Furthermore, where political tensions are organised around the structures of inequalities in land ownership, they result in violent conflicts that destabilise the basic foundation of that society.

In Rawls' hypothetical, the basic institutions of society represent these power structures, which according to him must be subjected to regulation and criticism in accordance with the principles of justice chosen by the society. As argued before, the primary legal sources in Kenya affirm the uncompromising nature of basic liberties and justice. No particular form of justice has been alluded to, but Article 60 of the Constitution and Sections 73 and 75 of the National Land Policy are categorical on the primacy of equity in the landholding sector.

Justice is the first virtue of social institutions. What does justice in the land sector constitute? The best way to perceive what such justice would be is by first understanding what the injustice has been. The themes discussed in the previous passages are meant to provide a clear picture of what historical injustices in land have constituted.

The promulgation of the Constitution and the enactment of the new land laws must mean that the people of Kenya agree that the state must do something about the multiple layers of land dispossession. This situation is congruent with Rawls' theory in at least two respects. First, there has been a rational decision, based on consensus that has established principles of justice that should regulate all further criticism of government. Second, there is a primary role assigned to the power structures that constitute the institutions at the pinnacle (of the basic structure) of society.

Having established the injustice, the necessity to correct it and the positive declaration of intention to correct it, if these ideas are not to be shelved and forgotten, it is imperative that we identify how best to effectuate this intention.

Some attempts have been made, as mentioned before, to remedy the land question. However, these have seemed to focus on immediate causes of landrelated conflicts, such as politically-charged ethnic claims to land. It is noteworthy that the root cause of the land problem is iniquitous landholding structures that have remained embedded in the country's political economy. If these remain

46 Mamdani M, Citizen and subject: Contemporary Africa and the legacy of late colonialism. Princeton, NJ: Princeton University Press, 1996. 
unaddressed, there is no guarantee that the conflicts which Kenya's history is rife with will not recur.

This paper identifies the legal process of Transitional Justice as the best avenue in pursuance of the goals articulated by the Constitution as well as the Rawlsian ideal.

\section{The Promise of Transitional Justice}

The previous sections have attempted to outline the issues which stand out the most in contemporary Kenyan society regarding land use and administration as well as the socioeconomic impact of decisions made at a political level. The discussion has also attempted to bring to the fore the relevance of core institutions (stakeholders) strategically placed to settle the land question in the political structures of government and legal institutions such as dispute-resolution agencies.

It has been argued that the contemporary land issues discussed have been occasioned by, in a nutshell: (i) iniquitous landholding structures embedded in the country's political economy (this contribution has submitted that this is the root cause of the land questions, the other being immediate causes or symptoms and incidents); (ii) inappropriate policies and priorities in resolving the root causes of land issues; (iii) dishonest and unscrupulous administration characterised by pillage and the usage of land as a political resource; (iv) myths and misconceptions regarding the role of informal settlements and other land-related phenomena in the country's socio-economic platform.

Armed conflict, authoritarianism and the humanitarian disasters and massive human rights abuses that often accompany them can have an immensely negative and long-lasting impact on development. As a result, transitional justice is often pursued in a context of severely underdeveloped economic and social institutions, widespread scarcity of resources and myriad competing needs. ${ }^{47}$ In the particular context of this paper, the abuses upon which transitional justice imperatives are brought to bear relate to land rights enumerated in, primarily, Article 60 of the Constitution as well as the principles underpinning the National Land Policy.

47 Office of the UN High Commissioner for Human Rights (OHCHR), Rule-of-Law Tools for PostConflict States: Prosecution Initiatives (New York and Geneva: United Nations, 2006). 
The UN High Commissioner for Human Rights Louise Arbour ${ }^{48}$ has argued for integrating economic, social and cultural rights into the transitional justice framework, thereby allowing justice, in its full sense, to make the contribution that it should to societies in transition. As argued extensively in this contribution, land is a critical economic, social and cultural resource, with far-reaching influences in these spheres of life. Such is the case for Kenya. It is therefore imperative that transitional justice be integrated into the processes that aim to streamline issues in these sectors, to ensure economic development (for all) and, more importantly, social cohesion.

Transitional justice can have a positive impact on development through direct effect and by helping create the conditions that facilitate development in the following ways: ${ }^{49}$ (i) such measures as individual and collective reparations, property restitution, rehabilitation and reintegrating victims and perpetrators may alleviate marginalisation, exclusion and vulnerability by bringing people and groups into the economy, recognising and empowering them as citizens and perhaps generating economic activity, and (ii) important conditions such as political and social stability, safety, access to justice, conflict prevention and social and economic justice that can foster development may be facilitated by transitional justice objectives, including addressing grievances, reconciling groups and restoring trust in institutions.

There are potential costs for transitional societies if transitional justice institutions continue to neglect the economic roots and consequences of conflict, in the absence of socioeconomic redistribution. 'The divorce of development strategies from transitional justice allows a myth to be formed that the origins of conflict are political or ethnic rather than economic or resource-based. ${ }^{50}$ This is a philosophy which could correctly guide reform institutions in Kenya, such as the National Land Commission, Commission for the Implementation of the Constitution, and the Ethics and Anti-Corruption Commission. An impunity gap results when transitional justice measures ignore accountability for large-scale corruption and economic crimes, and addressing poverty and social inequality must be regarded as among the strategic goals of any transitional justice undertaking. ${ }^{51}$ This

48 Arbour L, 'Economic and social justice for societies in transition' http://nyujilp.org/wp-content/ uploads/2013/02/40.1-Arbour.pdf on 31st August 2015.

49 Alexander J, A Scoping study of transitional justice and poverty reduction final report, Department for International Development (DFID), 2003.

50 Miller Z|, 'Effects of invisibility: In search of the 'Economic' in Transitional Justice', 2 International Journal of Transitional Justice, 3 (2008), 267-268.

51 Carranza R, 'Plunder and pain: Should transitional justice engage with corruption and economic 
perspective has important implications in light of the gross economic injustices that the many preceding passages discussed here have sought to bring to light.

To those who qualify transitional justice as a necessary process in certain contexts, one objection regards the diversion of resources which may conceivably be used to further other important ends. In response to this, it is important to note that it was this confounding of priorities that the independence Government of Kenya fell prey to. Economic stability should not be put ahead of social stability, since this may leave the underlying causes of conflict, which are structural inequalities, unaltered. This does not solve the problem but slowly exacerbates it, and eventually the whole system implodes. It is a lesson that Kenya has learnt the hard way.

Perhaps a more intelligible and plausible objection or qualification to transitional justice is one pointed out by Tonya Putnam, ${ }^{52}$ that transitional justice presupposes the existence of an entire set of functioning institutions to investigate, prosecute and punish individuals who commit human rights violations. In societies emerging from civil war, such institutions are normally weak or non-existent, if indeed they existed beforehand. An empirical study shows that the economic health of a country may in fact affect the decision to pursue transitional justice. ${ }^{53}$

In response to this, this contribution submits that Kenya is not exactly emerging from civil war, and that the issue at hand is systematic prejudice against lower-income and less-privileged sections of the population. Moreover, such institutions as are referred to are in their abundance - there is the Ethics and Anti-Corruption Commission, the National Land Commission, a relatively well-functioning judiciary and a very active and vocal civil society among other pressure groups. However, it is conceded here that political goodwill poses the most challenging hurdle (politicians may, and do, have vested interests in such regrettable realities as a dishonest landholding system) as evidenced by the apparent reluctance or lethargy of the political structures in the pursuance of justice against alleged perpetrators of the post- election violence, a process which was eventually taken up by the International Criminal Court.

Crimes?’, 2 International Journal of Transitional Justice, 3 (2008), 329.

52 Putnam T, 'Human rights and sustainable peace, in ending civil wars: The implementation of peace agreements', Stephen John Stedman (ed), Donald Rothchild, and Elizabeth Cousens (Boulder: Lynne Rienner Publishers, 2002).

53 Olsen T, Payne L, and Reiter A, 'At what cost? A political economy approach to transitional justice' (paper prepared for the Midwest Political Science Association Conference, Chicago, IL, 14 April 2007). 
At a broad level of generality, transitional justice and land relate to each other through the concept of the rule of law. ${ }^{54}$ For many countries, poor governance has resulted in conflict or authoritarian rule, and the recovery from these states of crisis depends on a radical shift in governance norms. Too much attention has historically been placed on the elaboration of laws, and too little to the ways in which those laws are interpreted and implemented..$^{55}$

A UN report ${ }^{56}$ has submitted that the increasing awareness of the importance of land issues in the rule-of-law field is to be welcomed, to the extent that rule-of-law programming goes beyond law reform ${ }^{57}$ and seeks to develop and operationalise an innovative approach to protecting land rights. This report defines 'transitional justice' as

"the full range of processes and mechanisms associated with a society's attempts to come to terms with a legacy of large-scale human rights abuses in order to ensure accountability, serve justice and achieve reconciliation.” As will be seen later, this definition has very comprehensive and important implications.

Due to the limited mandate (civil and human rights abuse) this concept has been applied to, it has often proven difficult to satisfactorily address these kinds of abuses for political and practical reasons. Thus the argument that transitional justice processes should seek to address gross violations of social, economic and cultural rights in addition to civil and political ones. ${ }^{58}$ Proponents argue that such crimes can be more widespread and severe than civil and political rights violations, involving more perpetrators and affecting more victims.

Because of its emphasis on successful transition, other values are also important such as democracy, stability, equity and fairness to victims and their families. The task is not simply to seek redress for abuses, but to democratise the

54 Mayer-Rieckh A and de Greiff P (eds), 'Justice as prevention: Vetting public employees in transitional societies'

55 Take for instance the actual implications of Section 73 of the National Land Policy and Article 60 (1) of The Constitution of Kenya (2010). The fact that these provisions are somewhat symbolic of the national consciousness of Kenyan society to land injustices goes without saying. However, the real question is whether these imperatives generate clear policy goals by which officials can be held accountable. Also, there are questions of the justiciability of these imperatives as well as the particular responsibilities of the correlative duty bearers.

56 FIAN International, Land Grabbing in Kenya and Mozambique: A report on two research missions and a human rights analysis of land grabbing, 2010.

57 It is noteworthy that land law reform in Kenya has made significant strides, and various principles to regulate entitlements/interests, use and administration are well-articulated. Whether the same has had meaningful consequences on the ground is debatable.

58 See, for instance, the Millennium Challenge Account. 
decision-making processes at all levels and in all sectors of societies. ${ }^{59}$ Important parallels may be drawn between this latter observation and the consensual decision of the entrants of the social contract in Rawls' hypothetical, who decide freely and rationally on the future principles of justice to guide their affairs.

The limited strategic planning and impact-evaluation of rule of law interventions has typically meant that the instruments of the state undergo some improvements- but the structures and dynamics of decision-making remain largely intact. A failure to address the political economy of decision-making will mean that power structures remain intact and changes are only superficial.

Furthermore, the constant gains in protecting human rights and combating impunity may be undone through an increasing emphasis on 'reconciliation' without accountability. This gives the impression that access to justice prevails in what remains a structurally unjust situation. It will be reiterated here that it is fundamental that these processes remain threefold to attain legitimacy; they must be legal, rectificatory and distributive.

With this in mind, one may be tempted to ask, 'How is Kenya a transitional society, and particularly why in the lands sector?' To complement the accounts that have been narrated regarding historical injustices, conflicts and poor governance that have characterised Kenya's economic, political and even cultural spheres (deliberate destruction of customary law forms and methods), the following paragraph should offer some specificity and direction.

The Ndung'u Report of the Commission for Irregular and Illegal Allocations of Public Land identified these problems as having characterised public land tenure. They include direct allocation by the President and/or Commissioner of Lands, contrary to law; illegal surrender of ministry and state corporation land and subsequent illegal allocations; invasion of government and trust lands and subsequent acquisition of titles to it contrary to law; allocation of land reserved for state corporations and ministries; allocation of trust lands contrary to the Constitution and related laws; allocation of riparian reserves and sites and allocation of land compulsorily acquired for the public interest to individuals and companies.

In the same vein, the National Land Policy goes further in enunciating the crisis that has become the land question. It states that the genesis of the problem was the colonial settler economy, which constituted disenfranchising of natives

59 Huggins C, 'Linking broad constellations of ideas: Transitional justice, land tenure reform, and development.' 
and systematic degradation of customary land tenure. It notes that hitherto existing policies and law in Kenya pursue economic productivity at the expense of other equally important values such as equity, sustainability and the preservation of culture. Furthermore, this 'economic productivity' is primarily a benefit of a few and has been achieved at the cost of severe incidents of inequality and gross abuses of economic and human rights.

The National Land Policy identifies some contemporary manifestations of the problem which include general disregard for land-use planning regulations; gross disparities in land ownership and inadequate environmental management and conflict over land and land-based resources. Above all this, Kenya has had to undergo the more appalling phenomenon of consistent bouts of violent conflicts over land and land-based resources, most recently the 2008 violence which almost reached genocidal proportions.

On account of the above factors, Kenya has entered into a period of transition with the promulgation of the Constitution and the enactment of new land laws whose rationale is to redress previous injustices including iniquitous land ownership structures. As stated earlier, limited strategic planning and impactevaluation of rule-of-law interventions will typically mean that even though the instruments of state undergo some improvements, the dynamics of decisionmaking and the iniquitous political economy will remain intact. It is advised that Kenyan society be wary of falling into this trap. Thus the significance of transitional justice processes in Kenyan society. As observed earlier, a key defining characteristic of transitional justice is the overt engagement with the processes of transition as well as adherence to domestic as well as international standards.

A significant setback that Kenya's land structure has suffered has been the neglect of customary and communal tenure. It has now become common knowledge in academic as well as policy circles ${ }^{60}$ that a market-led model of tenure reform is unsustainable as the dominant paradigm. It has also been demonstrated that in the African context there is no necessary causal link between individualisation of tenure and economic progress. ${ }^{61}$ Moreover, customary tenure systems have proven to be remarkably resilient, even in the face of government hostility and the forces of globalisation. ${ }^{6}$ This may be because they enjoy more local legitimacy than systems imposed by government. It is of note that the comparison

\footnotetext{
60 National Land Policy, Sessional Paper No. 3 of 2009.

${ }_{61}$ Nyamu C, 'Breathing life into dead theories about property rights', Institute of Development Studies.

62 See Ogendo O, 'The tragic African commons', on the resilience of customary land tenure.
} 
between customary tenure and 'underdeveloped economic systems yet to evolve' is unhelpful, given the vast cultural and political differences between the West and the developing world.

In light of the novel recognition of customary land tenure, it remains to be seen whether deliberate attempts at restitution toward the relevant communities and groups (remember the case of Westlands Market) ${ }^{63}$ will be effected, in a spirit of accountability and operationalising the rule of law.

It is such mechanisms of transition, reconciliation and accountability that will conclude this discussion.

A pivotal enabling condition for transitional justice is judicial reform. The process may even be impossible without these structures. This contribution will not dwell on this point seeing that the judicial structure in the country is relatively capable. As noted earlier, however, the real prerequisite for the process to move forward is the political goodwill of all stakeholders, citizens to demand retributive justice and restitution, for civil society and politicians to actively push for the agenda and the court to administer justice without fear (of political elites that benefited from injustices), or favour.

In deciding whether to pursue the course of transitional justice, a choice has to be made by the state between retaining the status quo, fully or partially returning to a previous status quo, or choosing a new status quo altogether. ${ }^{64}$ The decision of the state (which would be expected to conform to the rational will and perception of justice of the people) would determine who is considered the legitimate property-rights holder at law.

Retaining the status quo would essentially mean affirming the legitimacy of the market-led model of development that presently subsists. This would in effect mean that title to land would be vindicated regardless of how it was acquired. This move is likely to guarantee economic stability. However, its important flaw is that it engenders social resentment in the collective perception of those affected by past abuses. Moreover, this paper argues that protection of illegally acquired title goes against the spirit of the Constitution which has been viewed as a guarantee for change as well as its letter, particularly Article 40 which does not extend legal protection to illegally acquired property.

63 Rawls J, A Theory of justice, 3.

${ }^{64}$ Atuahene B, Property and transitional justice, 58 UCLA Law Review, 65 (2010) Available at: http:/ / scholarship.kentlaw.iit.edu/fac_schol/34 on 30 July 2015. 
The return to a prior status quo would involve the state using the present distribution as a starting point and using its powers of eminent domain to make land available for return to past owners. ${ }^{65}$ If the beneficiaries of unjust property rights transfer are readily available, they may be compelled to fully or partially finance restitution programs. If they are not identifiable, the state should finance these programs.

Creating a new status quo if implemented properly has the potential to equalize wealth and promote stability. ${ }^{66}$ Redistribution would in this case be through tax or equalization of land ownership. It has been argued ${ }^{67}$ that the former method is more efficient.

The redistributive measures that may be applied here may be reparations or restorations. ${ }^{68}$ In the former program victims do not have a choice of what compensation they will receive; the state instead makes the decision after determining their eligibility. In the latter, the subject is allowed to participate in the determination of compensation in order to ensure their re-entry into the social contract.

In returning to a previous status quo the hurdles to be surmounted will include $^{69}$ identification of beneficiaries, obtaining verifiable proof of ownership or occupation, acknowledging the people who owned nothing in the past, the proper usage of the power of eminent domain, transcending inefficiency and corruption on the part of government and determining how far back the reparation measures should look.

\section{Some Remarks on Rawlsian Justice}

The first principle of justice as fairness is that every individual should enjoy the full range of rights that are compatible with the basic liberties of others. It has been demonstrated that land ownership structure has been deliberately skewed to favour a very small segment of the population at the expense of the majority who are smallholders or inhabitants of informal settlements.

Atuahene B, 'Property and transitional justice.'

Atuahene B, 'Property and transitional justice.'

Kaplow L and Shavell S, 'Why the legal system is less efficient than the income tax in redistributing income.'

68 Kaplow L and Shavell S, 'Why the Legal System Is Less Efficient Than the Income Tax in Redistributing Income.'

69 Atuahene B, 'Property and transitional justice.' 
The second principle of justice as fairness would require that any inequalities in a society should be designed in such a manner that they are to the greatest benefit of the least advantaged. Inequalities in land rights in Kenyan society have been shown to be debilitating and even dehumanizing, for instance in the case of forced evictions and slums.

Rawls provides that these principles are to be arranged and pursued in a lexical order. ${ }^{70}$ 'A principle does not come into play until those previous to it are fully met or do not apply.' With the historical injustices discussed with regard to land, it is hard to conceive of the second principle as directly applicable; the first, despite being affirmed by legal sources, has not been fully met. To this extent, but arguably, ${ }^{71}$ the second principle is not particularly relevant as a framework for structuring Kenya's political and social Constitution.

\section{Conclusion}

Presently, the substantive realities of the land question in Kenya betray the uncompromising principles that are justice and the guarantee of basic liberties imposed by the Constitution and enacted land laws. Procedurally, bold steps need to be taken to bring these realities into unity with the notions of justice as fairness.

In particular, other than reforming the instruments of state that have led to these abuses, care should be had to the power structures that in nuanced ways have influenced the conduct of these instruments. Here lies the importance of transitional justice mechanisms. When well-implemented, they are blind and possibly immune to such external or political influences. This is contrasted to such measures as settlement schemes and attendant land titling which have proved to be myopic and responsive to immediate rather than deep-rooted causes of iniquitous land distribution.

Such measures should include the enactment of an informal settlements policy and the active pursuance of the transitional measures of land redistribu-

70 Rawls J, A Theory of justice, 61.

71 Arguable because of the contention that it is impracticable to revert to a position of equality when property irregularly acquired is transferred to a bona fide third party. See Robert Nozick's three principles that cover the subject of justice in holdings in Anarchy, State and Utopia. In response to this, however, this paper argues that Nozick concedes, in his entitlement theory, that rectification of injustice in holdings is a principle of justice. 
tion that include restorations and reparations. The merits and demerits of the different approaches to the issue of the status quo have been outlined.

This contribution does not presume that the logical-or factual- end of the processes of transitional justice in the Kenyan situation would be to yield a state of affairs perfectly congruent to the Rawlsian hypothetical. The fine points underlying this observation have been discussed. Nevertheless, the arm of justice will swing and strike. 